\title{
Pengaruh Pemberian Pupuk NPK Phoska dan Pupuk Organik Cair Terhadap Pertumbuhan dan Produksi Tanaman Pisang Rutai ( Musa sp )
}

\section{The Influence of NPK Phoska Fertilizer and Liquid Organic Fertilizer on Banana Plant Growth and Production Rutai (Moses sp)}

\author{
Teguh Martono ${ }^{1}$, Purwati ${ }^{2}$, Iin Arsensi ${ }^{2}$ \\ ${ }^{1}$ Alumni Program Studi Agroteknologi, Fakultas Pertanian, Universitas Widya Gama Mahakam \\ ${ }^{2}$ Tenaga Pendidik Program Studi Agroteknologi, Fakultas Pertanian, Universitas Widya Gama Mahakam \\ Jl. KH. Wahid Hasyim, Sempaja, Samarinda, Kalimantan Timur, Indonesia \\ email : martonoteguh@gmail.com, purwati@uwgm.ac.id, iinarsensi@uwgm.ac.id
}

Diterima : 24 Agustus 2017 Disetujui : 13 Oktober 2017

\begin{abstract}
The Influence of NPK Phoska Fertilizer and Liquid Organic Fertilizer on Banana Plant Growth and Production (Musa sp). The purpose of this study was to determine the effect of NPK Phoska fertilizer and liquid organic fertilizer on the growth and production of banana rutai plant. The study was conducted for 7 (seven) months, from February to September 2015, starting from land preparation to data collection. This research was conducted on campus of Widya Gama Mahakam Samarinda. The research design used was factorial randomized block design $3 x$ 3 with 3 times replication. The first factor was Phoska NPK fertilizer $(P)$ consisting of 3 levels: P0 (Without Treatment), P1 (1080 g/ plant) and P2 (1580 g / plant). The second factor is the application of liquid organic fertilizer (B) 3 levels, namely: B0 (Without treatment), B1 $(5000 \mathrm{ml})$ and B2 $(10000 \mathrm{ml})$. The result of the research showed that the best treatment of NPK Phoska P2 (1580 g/ plant) was the average of plant height 90 days after the highest treatment was $122.33 \mathrm{~cm}$, the largest mean stem diameter was $11,08 \mathrm{~cm}$ and average the highest number of comb per bunches is $7.22 \mathrm{comb}$, the fastest harvest age is 248 days after planting. The best treatment of liquid organic fertilizer to the average number of combs per cluster was achieved at the treatment of B1 $(5000 \mathrm{ml})$ ie 5.33 comb, the fastest harvest age 248 days after planting. The interaction between NPK Phoska fertilizer application and liquid organic fertilizer did not significantly affect all observation parameters.
\end{abstract}

\section{Keywords: NPK Phonska, liquid organic fertilizer and banana rutai}

\section{PENDAHULUAN}

Pisang adalah buah yang sangat bergizi yang merupakan sumber vitamin, mineral dan juga karbohidrat. Tanaman pisang banyak dimanfaatkan oleh masyarakat luas untuk berbagai macam keperluan hidup. Bagian tanaman pisang selain buah, mulai dari akarnya sampai dengan daunnya banyak dimanfaatkan orang untuk berbagai keperluan, tidak ada bagian tanaman tersisa untuk tidak dapat dimanfaatkan apabila masyarakat dapat mengetahuinya secara luas khasiat yang sebenarnya ada pada tanaman pisang (Cahyono, 1996).

Buah pisang hinga saat ini dijadikan, sale pisang, pure pisang, tepung pisang dan juga dapat menjadi makanan pembuka dan penutup. Selain itu kulit pisang dapat dimanfaatkan untuk membuat cuka melalui proses fermentasi alkohol dan asam cuka. Daun pisang dipakai sebagi pembungkus berbagai macam makanan trandisional Indonesia. Batang pisang diolah menjadi serat untuk pakaian, kertas dan lainlain. Batang pisang yang telah dipotong kecil dan daun pisang dapat dijadikan makanan ternak (domba, kambing) pada saat musim kemarau dimana rumput tidak/kurang tersedia (Cahyono, 1996).

Produksi tanaman pisang di Kalimantan Timur pada tahun 2011 dengan jumlah pohon 2.183.667 sebesar 122.541 ton dan pada tahun 2012 dengan jumlah pohon 1.810 .820 menghasilkan produksi 112.917 ton (Deptan, 2012).

Salah satu jenis buah yang kini juga mulai langka adalah pisang rutai. Buah pisang rutai berukuran kecil, rasanya manis, sifatnya dingin, astringen, melumas usus, penawar racun, penurun panas, anti radang, peluruh kencing, akar berkasiat sebagai penawar racun, pereda demam, mendinginkan darah, hati batang pisang berkasiat penurun panas dan untuk perawatan rambut. Cairan dari bonggol mengatasi infeksi saluran kencing, menghentikan pendarahan, penurun panas, serta penghitam dan mencegah rambut rontok (Deptan, 2012).

Pengembangan pisang rutai hingga saat ini masih diusahakan oleh masyarakat hanya sebagai pengisi tanah pekarangan rumah ataupun pada pematang-pematang sawah dan tegalan. Usaha ini masih merupakan usaha tani subsisten yang tidak memperhatikan teknik budidaya pertanian yang intensif. Sistem 
pembudidayaan pisang secara tradisional ini pada kenyataannya tidak dapat berproduksi secara maksimal. Tanaman pisang yang dibudidayakan secara intensif dengan menerapkan teknologi yang benar dapat memberikan keuntungan yang tinggi dan mampu bersaing dengan tanaman yang lain.

Teknik budidaya yang intensif dapat dilakukan dengan berbagai cara, dengan memperhatikan keadaan lingkungan khususnya tempat tumbuhnya tanaman yaitu tanah sebagai media tumbuh. Wilayah Kalimantan Timur terutama wilayah Samarinda mempunyai kondisi tanah yang didominasi oleh jenis tanah podsolik (ultisol), jenis tanah ini mempunyai ciri proses pencucian (leaching) sehingga kehilangan unsur hara sering terjadi. Oleh karena itu pada tanahtanah dengan kondisi tersebut perlu dilakukan penambahan unsur hara melalui pemupukan.

Keberhasilan produksi suatu tanaman sangat ditentukan dengan unsur hara yang cukup. Menurut Harjadi (2002), tanaman membutuhkan unsur hara untuk melakukan proses-proses metabolisme, terutama pada masa vegetatif. Kebutuhan akan unsur hara dapat dilakukan dengan cara pemupukan mengunakan pupuk organik maupun anorganik.

Penggunaan pupuk anorganik juga diperlukan untuk memacu pertumbuhan tanaman. Pupuk anorganik terdiri dari pupuk tunggal dan pupuk majemuk. Pupuk majemuk merupakan pupuk campuran yang umumnya mengandung lebih dari satu macam unsur hara, makro maupun mikro terutama $\mathrm{N}, \mathrm{P}$ dan $\mathrm{K}$ (Rosmarkam dan Yuwono, 2002). Dengan satu kali pemberian pupuk dapat mencakup beberapa unsur, sehingga lebih efisien bila dibandingkan dengan pupuk tunggal. Kelebihan lain dari penggunaan pupuk majemuk yaitu pupuk NPK

\section{BAHAN DAN METODE}

Penelitin ini di lakukan 7 (tujuh) bulan, sejak bulan Februari sampai dengan bulan September 2015, dimulai dari persiapan lahan sampai pengambilan data. Penelitian ini dilaksanakan di lahan kampus Widya Gama Mahakam Samarinda. Bahan kimia untuk analisis tanah, pupuk organik cair yang difermentasikan sendiri, pupuk NPK Phoska, air dan bibit tanaman pisang rutai berasal dari peneliti sebelumnya yang melaksanakan penelitian dari bonggol pisang hingga menjadi tanaman pisang berumur 8 bulan. Penelitian ini di susun dalam Rancangan Acak Kelompok Faktorial dengan percobaan faktorial 3 x 3 dengan 3 (tiga) ulangan. Perlakuan terdiri dari 2
Phoska adalah menghemat waktu, tenaga kerja dan biaya pengangkutan (Hardjowigeno, 2007).

Pupuk anorganik mampu meningkatkan produktivitas tanah dalam waktu singkat, tetapi penggunaan yang dilakukan secara terus menerus akan mengakibatkan kerusakan pada struktur tanah (tanah menjadi keras) dan menurunkan produktivitas tanaman yang dihasilkan (Mulyani, 2008). Oleh karena itu pemberian pupuk anorganik perlu diimbangi dengan pemberian pupuk organik agar penurunan kualitas tanah dapat dikurangi.

Pupuk organik mengandung unsur hara makro yang rendah tetapi juga mengandung unsur mikro dalam jumlah cukup yang sangat diperlukan untuk pertumbuhan tanaman karena mempengaruhi sifat fisik tanah, sifat kimia, dan sifat biologi tanah, juga mencegah erosi dan mengurangi terjadinya keretakan tanah (Mulyani, 2008).

Pupuk organik cair yang berasal dari sisa kotoran hewan memiliki kandungan unsur makro yang meliputi $\mathrm{N}, \mathrm{P}, \mathrm{K}, \mathrm{Ca}, \mathrm{Mg}$, dan $\mathrm{S}$, sedangkan unsur hara mikro meliputi $\mathrm{Fe}, \mathrm{Mn}$, $\mathrm{Cu}$, dan $\mathrm{Zn}$, sehingga baik untuk digunakan sebagai unsur hara bagi tanaman, dan dapat memperbaiki sifat fisik dan biologi tanah (Hardjowigeno, 2007).

Penggunaan pupuk dalam budidaya tanaman sangat diperlukan untuk mendorong proses pertumbuhan vegetatif yang baik. Penggunaan pupuk organik cair dengan konsentrasi dan interval waktu yang tepat diharapkan mampu meningkatkan pertumbuhan dan produksi tanaman.

Berdasarkan uraian tersebut diatas maka perlu dilakukan penelitian mengenai pengaruh pemberian pupuk NPK Phoska dan pupuk organik cair terhadap pertumbuhan dan produksi tanaman pisang rutai (Musa sp).

faktor. Faktor pertama yaitu pemberian pupuk NPK Phoska (P) yang terdiri dari 3 taraf : $\mathrm{P}_{0}$; Tanpa Perlakuan, $\mathrm{P}_{1} ; 1080 \mathrm{~g} /$ tanaman, $\mathrm{P}_{2} ; 1580$ g/tanaman dan faktor yang kedua yaitu pemberian pupuk organik cair (B) 3 taraf yaitu : $\mathrm{B}_{0} \quad=$ Tanpa perlakuan, $\mathrm{B}_{1}=500$ $\mathrm{ml} / 2$ minggu / (5.000 $\mathrm{ml} /$ tanaman) selama 5 bulan, $\mathrm{B}_{2}=1000 \mathrm{ml} / 2$ minggu $/(10.000 \mathrm{ml} /$ tanaman) selama 5 bulan. Pelaksanaan penelitian meliputi pembuatan pupuk organic cair, pengambilan sampel tanah, penyiapan lahan, penanaman tanaman pisang, pemeliharan meliputi ; penyiangan, pembuatan drainase, pemupukan, penjarangan dan panen. Pengambil data meliputi ; pertambahan tinggi tanaman, 
pertambahan diameter batang, diameter batang, umur muncul dan jumlah sisir pertandan. Data dianalisis dengan menggunakan sidik ragam,

\section{HASIL DAN PEMBAHASAN}

\section{Pupuk NPK Phoska}

\section{Pertambahan Tinggi}

Hasil sidik ragam menunjukkan bahwa perlakuan pemberian pupuk NPK Phoska berbeda sangat nyata terhadap rata-rata pertambahan tinggi tanaman umur 30, 60 dan 90 hari setelah perlakuan dan pertambahan diameter batang umur 30, 60 dan 90 hari setelah perlakuan. Pada umur 90 hari setelah perlakuan, perlakuan $\mathrm{P}_{2}$ memberikan hasil yang terbaik pada masing-masing parameter yaitu pertambahan tinggi tanaman $(122,33 \mathrm{~cm})$ dan pertambahan diameter batang $(11,08 \mathrm{~cm})$. Hal ini diduga bahwa dengan dosis yang tepat maka pertumbuhan vegetatif tanaman akan berjalan dengan baik. Sesuai dengan pendapat Hidayanto, dkk (2003), proses pembelahan, pemanjangan dan deferensiasi sel tergantung jumlah karbohidrat. Apabila laju pembelahan dan pemanjangan sel, serta pembentukan jaringan berjalan cepat, maka pertumbuhan akar, batang dan daun juga akan cepat. Ditambahkan oleh Harjadi (2003), fase vegetatif mengacu kepada perkembangan akar dan batang yang dipengaruhi oleh unsur hara yang diterima oleh tanaman, sehingga senyawa organik seperti karbohidrat, protein dan lemak sangat diperlukan dalam pembentukan jaringan baru. Walaupun kondisi lahan penelitian miskin akan unsur hara namun dengan kondisi tanaman pisang yang sudah berusia 8 bulan dan sudah mempunyai perakaran yang sempurna, pupuk NPK Phoska yang diberikan pada tanaman dapat diserap secara maksimal, sehingga memperlancar proses metabolisme tanaman pada fase vegetatif.

Menurut pendapat Hardjowigeno (2007), bahwa pertumbuhan dan perkembangan tanaman membutuhkan unsur hara, air, cahaya matahari dan ruang yang cukup tersedia. Sistem apabila terdapat pengaruh pada sidik ragam maka dilakukan uji BNT pada taraf 5\% untuk membandingkan data rata-rata perlakuan. perakaran yang baik dapat meningkatkan kemampuan tanaman untuk menyerap unsur hara yang diberikan. Ditambahkan oleh Lingga dkk (2010), bahwa unsur N, P, dan K dapat meningkatkan pertumbuhan tanaman. Nitrogen mempunyai peranan penting bagi tanaman untuk merangsang pertumbuhan vegetatif yaitu menambah tinggi tanaman dan membuat tanaman menjadi lebih hijau karena merupakan bahan penyusun klorofil yang penting dalam fotosintesis. Unsur P dapat meningkatkan laju fotosintesis dan merangsang pembentukan daun baru yang menyebabkan berat kering tanaman bertambah, selain itu unsur $\mathrm{P}$ diperlukan untuk merangsang pertumbuhan akar, pembentukan bunga dan buah. Kalium mempunyai peranan penting terhadap peristiwa fisiologis tanaman, diantaranya yaitu pengaktif dari sejumlah besar enzim yang penting untuk fotosintesis, respirasi, pembentukan pati dan protein.

Diperjelas oleh Gardner dkk (1991), bahwa semakin banyak hasil asimilasi yang dihasilkan berarti semakin banyak pula asimilat yang dibagikan pada akar dan daun. Daun yang menjadi daerah pembagian asimilat akan memanfaatkannya untuk pemanjangan dan pelebaran daun sehingga tanaman pisang akan mengalami peningkatan tinggi tanaman dan diameter batang. Perlakuan $\mathrm{P}_{0}$ memberikan hasil yang terkecil pada masing-masing parameter yaitu pertambahan tinggi tanaman $(61,44 \mathrm{~cm})$ dan pertambahan diameter batang $(5,64 \mathrm{~cm})$. hal ini diduga karena tidak adanya unsur hara yang tersedia sehingga pertumbuhan tanaman menjadi rendah. Sesuai dengan pendapat Jumin (2002), bahwa apabila jumlah hara makro dan mikro yang tersedia semakin sedikit, maka hara yang diserap tanaman akan semakin sedikit pula, hal akan ini berakibat pada proses fotosintesa yang akan dihasilkanpun sedikit, akibatnya pertumbuhan vegetatif tanaman menjadi rendah.

Tabel 1. Pengaruh Pemberian Pupuk NPK Phoska dan Pupuk Organik Cair Terhadap Rata-Rata Pertambahan Tinggi Tanaman Umur 30 Hari Setelah Perlakuan.

\begin{tabular}{ccccc}
\hline \multirow{2}{*}{ Pupuk Organik Cair } & \multicolumn{3}{c}{ NPK Phoska } & \multirow{2}{*}{ Rata-Rata } \\
\cline { 2 - 4 } & $\mathrm{P}_{0}$ & $\mathrm{P}_{1}$ & $\mathrm{P}_{2}$ & \\
\hline $\mathrm{B}_{0}$ & 9,67 & 30,00 & 35,33 & 25,00 \\
$\mathrm{~B}_{1}$ & 8,33 & 20,67 & 42,67 & 23,89 \\
$\mathrm{~B}_{2}$ & 13,67 & 26,00 & 31,00 & 23,56 \\
\hline Rata-Rata & $10,56^{\mathrm{c}}$ & $25,56^{\mathrm{b}}$ & $36,33^{\mathrm{a}}$ & 24,15 \\
\hline
\end{tabular}

Keterangan : Angka rata-rata yang diikuti huruf yang sama menunjukkan tidak berbeda nyata pada uji BNT $5 \%$ $\left(\mathrm{BNT}_{\mathrm{P}}=7,68\right)$ 
Tabel 2. Pengaruh Pemberian Pupuk NPK Phoska dan Pupuk Organik Cair Terhadap Rata-Rata Pertambahan Tinggi Tanaman Umur 60 Hari Setelah Perlakuan.

\begin{tabular}{ccccc}
\hline \multirow{2}{*}{ Pupupk Organik Cair } & \multicolumn{3}{c}{ NPK Phoska } & \multirow{2}{*}{ Rata-Rata } \\
\cline { 2 - 4 } & $\mathrm{P}_{0}$ & $\mathrm{P}_{1}$ & $\mathrm{P}_{2}$ & 64,56 \\
$\mathrm{~B}_{0}$ & 39,67 & 73,00 & 81,00 & 63,33 \\
$\mathrm{~B}_{1}$ & 29,00 & 52,67 & 108,33 & 60,11 \\
$\mathrm{~B}_{2}$ & 43,67 & 59,33 & 77,33 & 62,67 \\
\hline Rata-Rata & $37,44^{\mathrm{c}}$ & $61,67^{\mathrm{b}}$ & $88,89^{\mathrm{a}}$ & \\
\hline
\end{tabular}

Keterangan : Angka rata-rata yang diikuti huruf yang sama menunjukkan tidak berbeda nyata pada uji BNT $5 \%$ $\left(\mathrm{BNT}_{\mathrm{P}}=14,77\right)$

Tabel 3. Pengaruh Pemberian Pupuk NPK Phoska dan Pupuk Organik Cair Terhadap Rata-Rata Pertambahan Tinggi Tanaman Umur 90 Hari Setelah Perlakuan.

\begin{tabular}{ccccc}
\hline \multirow{2}{*}{ Pupuk Organik Cair } & \multicolumn{3}{c}{ NPK Phoska } & \multirow{2}{*}{ Rata-Rata } \\
\cline { 2 - 4 } & $\mathrm{P}_{0}$ & $\mathrm{P}_{1}$ & $\mathrm{P}_{2}$ & \\
\hline $\mathrm{B}_{0}$ & 57,33 & 109,33 & 105,33 & 90,67 \\
$\mathrm{~B}_{1}$ & 54,33 & 86,00 & 143,67 & 94,67 \\
$\mathrm{~B}_{2}$ & 72,67 & 98,67 & 118,00 & 96,44 \\
\hline Rata-Rata & $61,44^{\mathrm{b}}$ & $98,00^{\mathrm{a}}$ & $122,33^{\mathrm{a}}$ & 93,93 \\
\hline
\end{tabular}

Keterangan : Angka rata-rata yang diikuti huruf yang sama menunjukkan tidak berbeda nyata pada uji BNT $5 \%$ $\left(\mathrm{BNT}_{\mathrm{P}}=29,41\right)$

Tabel 4. Pengaruh Pemberian Pupuk NPK Phoska dan Pupuk Organik Cair Terhadap Rata-Rata Pertambahan Diameter Batang Umur 30 Hari Setelah Perlakuan.

\begin{tabular}{ccccc}
\hline \multirow{2}{*}{ Pupuk Organik Cair } & \multicolumn{3}{c}{ NPK Phoska } & \multirow{2}{*}{ Rata-Rata } \\
\cline { 2 - 4 } & $\mathrm{P}_{0}$ & $\mathrm{P}_{1}$ & $\mathrm{P}_{2}$ & 2,09 \\
$\mathrm{~B}_{0}$ & 1,16 & 2,46 & 2,66 & 2,78 \\
$\mathrm{~B}_{1}$ & 0,90 & 1,81 & 5,63 & 1,80 \\
$\mathrm{~B}_{2}$ & 1,04 & 2,16 & 2,21 & 2,23 \\
\hline Rata-Rata & $1,03^{\mathrm{b}}$ & $2,14^{\mathrm{ab}}$ & $3,50^{\mathrm{a}}$ & \\
\hline
\end{tabular}

Keterangan : Angka rata-rata yang diikuti huruf yang sama menunjukkan tidak berbeda nyata pada uji BNT $5 \%$ $\left(\mathrm{BNT}_{\mathrm{P}}=1,50\right)$

Tabel 5. Pengaruh Pemberian Pupuk NPK Phoska dan Pupuk Organik Cair Terhadap Rata-Rata Pertambahan Diameter Batang Umur 60 Hari Setelah Perlakuan.

\begin{tabular}{ccccc}
\hline \multirow{2}{*}{ Pupuk Organik Cair } & \multicolumn{3}{c}{ NPK Phoska } & \multirow{2}{*}{ Rata-Rata } \\
\cline { 2 - 4 } & $\mathrm{P}_{0}$ & $\mathrm{P}_{1}$ & $\mathrm{P}_{2}$ & 5,69 \\
$\mathrm{~B}_{0}$ & 3,79 & 6,11 & 7,17 & 5,98 \\
$\mathrm{~B}_{1}$ & 3,02 & 4,54 & 10,39 & 4,89 \\
$\mathrm{~B}_{2}$ & 3,83 & 5,13 & 5,71 & 5,52 \\
\hline Rata-Rata & $3,55^{\mathrm{b}}$ & $5,26^{\mathrm{b}}$ & $7,76^{\mathrm{a}}$ & \\
\hline
\end{tabular}

Keterangan : Angka rata-rata yang diikuti huruf yang sama menunjukkan tidak berbeda nyata pada uji BNT $5 \%$ $\left(\mathrm{BNT}_{\mathrm{P}}=2,18\right)$

Tabel 6. Pengaruh Pemberian Pupuk NPK Phoska dan Pupuk Organik Cair Terhadap Rata-Rata Pertambahan Diameter Batang Umur 90 Hari Setelah Perlakuan.

\begin{tabular}{ccccc}
\hline \multirow{2}{*}{ Pupuk Organik Cair } & \multicolumn{3}{c}{ NPK Phoska } & \multirow{2}{*}{ Rata-Rata } \\
\cline { 2 - 4 } & $\mathrm{P}_{0}$ & $\mathrm{P}_{1}$ & $\mathrm{P}_{2}$ & \\
\hline $\mathrm{B}_{0}$ & 6,16 & 8,14 & 11,15 & 8,48 \\
$\mathrm{~B}_{1}$ & 5,30 & 7,10 & 13,52 & 8,64 \\
$\mathrm{~B}_{2}$ & 5,47 & 7,38 & 8,58 & 7,14 \\
\hline Rata-Rata & $5,64^{\mathrm{a}}$ & $7,54^{\mathrm{a}}$ & $11,08^{\mathrm{b}}$ & 8,09 \\
\hline
\end{tabular}

Keterangan : Angka rata-rata yang diikuti huruf yang sama menunjukkan tidak berbeda nyata pada uji BNT $5 \%$ $\left(\mathrm{BNT}_{\mathrm{P}}=2,40\right)$ 
Tabel 7. Pengaruh Pemberian Pupuk NPK Phoska dan Pupuk Organik Cair Terhadap Rata-Rata Saat Muncul Bunga.

\begin{tabular}{ccccc}
\hline \multirow{2}{*}{ Pupuk Organik Cair } & \multicolumn{3}{c}{ NPK Phoska } & \multirow{2}{*}{ Rata-Rata } \\
\cline { 2 - 4 } & $\mathrm{P}_{0}$ & $\mathrm{P}_{1}$ & $\mathrm{P}_{2}$ & 162,78 \\
$\mathrm{~B}_{0}$ & 77,67 & 212,00 & 198,67 & 168,11 \\
$\mathrm{~B}_{1}$ & 82,33 & 233,33 & 188,67 & 165,56 \\
$\mathrm{~B}_{2}$ & 65,00 & 227,67 & 204,00 & 165,48 \\
\hline Rata-Rata & $75,00^{\mathrm{a}}$ & $224,33^{\mathrm{b}}$ & $197,11^{\mathrm{b}}$ & \\
\hline
\end{tabular}

Keterangan : Angka rata-rata yang diikuti huruf yang sama menunjukkan tidak berbeda nyata pada uji BNT $5 \%\left(\mathrm{BNT}_{\mathrm{P}}=73,61\right)$

Tabel 8. Pengaruh Pemberian Pupuk NPK Phoska dan Pupuk Organik Cair Terhadap Rata-Rata Jumlah Sisir per Tandan.

\begin{tabular}{ccccc}
\hline \multirow{2}{*}{ Pupuk Organik Cair } & \multicolumn{3}{c}{ NPK Phoska } & \multirow{2}{*}{ Rata-Rata } \\
\cline { 2 - 4 } & $\mathrm{P}_{0}$ & $\mathrm{P}_{1}$ & $\mathrm{P}_{2}$ & 5,22 \\
$\mathrm{~B}_{0}$ & 2,00 & 6,67 & 7,00 & 5,33 \\
$\mathrm{~B}_{1}$ & 2,00 & 6,67 & 7,33 & 5,33 \\
$\mathrm{~B}_{2}$ & 2,00 & 6,67 & 7,33 & 5,30 \\
\hline Rata-Rata & $2,00^{\mathrm{a}}$ & $6,67^{\mathrm{b}}$ & $7,22^{\mathrm{b}}$ & \\
\hline
\end{tabular}

Keterangan : Angka rata-rata yang diikuti huruf yang sama menunjukkan tidak berbeda nyata pada uji BNT $5 \%$ $\left(\mathrm{BNT}_{\mathrm{P}}=1,79\right)$

\section{Saat Muncul Bunga.}

Hasil sidik ragam menunjukkan bahwa perlakuan pemberian pupuk NPK Phoska berbeda sangat nyata terhadap rata-rata saat muncul bunga (lampiran 10). Hal ini diduga bahwa dengan pemberian pupuk NPK Phoska dapat mempercepat pembentukan bunga pada tanaman.

Menurut Lingga, dkk (2010), suatu tanaman akan tumbuh subur bila elemen yang tersedia cukup dan sesuai dengan kebutuhan tanaman, penambahan unsur hara yang tepat akan menghasilkan pertumbuhan vegetatif maupun generatif yang sebanding dengan unsur hara yang diberikan. Ditambahkan Indrasaril dkk (2006), bahwa pemberian unsur hara baik makro dan mikro dalam jumlah yang cukup dan seimbang, mampu meningkatkan nutrisi yang diperlukan oleh tanaman dan digunakan sebagai sumber energi bagi tanaman.

\section{Jumlah Sisir per Tandan}

Hasil sidik ragam menunjukkan bahwa perlakuan pemberian pupuk NPK Phoska berbeda sangat nyata terhadap rata-rata saat muncul bunga (lampiran 10). Perlakuan $\mathrm{P}_{2}$ memberikan hasil yang terbaik yaitu (7,22 sisir), sedangkan perlakuan $\mathrm{P}_{0}$ memberikan hasil yang terkecil yaitu (2,00 sisir). Hal ini diduga dengan pemberian pupuk NPK Phoska 15:15:15 dapat memenuhi kebutuhan unsur hara yang diperlukan oleh tanaman pada fase generatif. Peningkatan hasil dipengaruhi oleh laju asimilasi tanaman pada fase generatif tanaman.

Menurut Mulyani (2008), pada fase pembentukan hasil dibutuhkan laju produksi dan alokasi asimilat yang tinggi ke buah. Laju fotosintesis untuk produksi asimilat tentu sangat dipengaruhi oleh ketersediaan unsur hara. Kandungan unsur hara $\mathrm{P}$ yang terdapat pada pupuk NPK Phoska membantu proses asimilasi tersebut. Ditambahkan Lingga dan Marsono (2005), unsur P bagi tanaman berguna sebagai bahan mentah untuk pembentukan sejumlah protein tertentu, membantu asimilasi dan pernapasan, serta mempercepat pembungaan, pemasakan biji dan buah.

Diperjelas oleh Wangiyana dkk (2011), untuk pembentukan dan pembesaran buah, maka harus ada pasokan fotosintat yang tinggi, yang tentu bersumber dari daun sebagai organ fotosintetik, selain pasokan $\mathrm{N}$ yang tinggi.

\section{Pupuk Organik Cair}

Hasil sidik ragam menunjukkan bahwa perlakuan pemberian pupuk organik cair tidak berpengaruh nyata terhadap semua parameter pengamatan yaitu pertambahan tinggi tanaman umur 30, 60 dan 90 hari setelah perlakuan, pertambahan diameter batang umur 30,60 dan 90 hari setelah perlakuan, saat muncul bunga dan jumlah sisir per tandan (lampiran 4, 5, 6, 7, $8,9,10$ dan 11). Hal ini diduga berkaitan dengan lahan yang digunakan tergolong mempunyai $\mathrm{pH}$ rendah (asam). Berdasarkan hasil analisa tanah, $\mathrm{pH}$ lahan adalah 4,26, kation basa $\mathrm{Ca}^{++}, \mathrm{Mg}^{++}$, $\mathrm{K}^{+}$dan $\mathrm{Na}^{+}$sangat rendah, dan KTK juga rendah, sehingga pemberian pupuk kurang efektif atau dengan kata lain unsur hara yang diberikan tidak dapat diserap akar tanaman secara optimal. Menurut Sutanto (2002), bahwa pupuk organik cair merupakan hasil fermentasi 
bahan organik dengan teknologi EM-4 yang dapat digunakan sebagai pupuk organik untuk menyuburkan tanah dan meningkatkan pertumbuhan dan produktifitas tanaman. Ditambahkan oleh Mulyani (2008), pemupukan tidak akan berpengaruh terhadap perkembangan vegetatif dan generatif tanaman apabila pupuk yang diberikan belum diserap seluruhnya oleh tanaman. Selain itu bahwa apa yang terdapat dalam tubuh tanaman sangat berhubungan dengan pertumbuhannya, dikatakan bahwa pertumbuhan tanaman akan berlangsung baik apabila kadar unsur hara yang terkandung dalam tanah tempat tumbuhnya masih baik. Kemudian diperjelas oleh Novizan (2002), pupuk organik merupakan pupuk alam yang melepaskan unsur hara secara perlahan-lahan sehingga tidak memiliki efek residu di dalam tanah dan bermanfaat bagi tanaman berikutnya. Pada perlakuan $\mathrm{B}_{1}(5.000 \mathrm{ml} / \mathrm{tanaman})$ menunjukkan hasil jumlah sisir per tandan lebih besar dibandingkan pada perlakuan $\mathrm{B}_{2} \quad(10.000$ $\mathrm{ml} /$ tanaman). Hal ini diduga pada perlakuan $\mathrm{B}_{1}$ mampu meningkatkan serapan unsur hara oleh tanaman dan kemudian dapat memicu tinggi tanaman. Sedangkan pada perlakuan $\mathrm{B}_{2}$ hasil jumlah sisir per tandan cenderung menurun, hal ini diduga dengan penambahan dosis pupuk organik cair menyebabkan bertambahnya hara yang tersedia, sehingga terjadi kelebihan hara yang diserap tanaman. Hal ini akan mengganggu keseimbangan hara yang diserap, sehingga akan menekan pertumbuhan dan produktifitas tanaman. Sesuai dengan pendapat Pranata (2004), bahwa semakin tinggi konsentrasi pupuk organik cair yang diberikan maka kandungan unsur hara yang diperoleh tanaman akan semakin banyak, sehingga dapat mempengaruhi pertumbuhan dan hasil tanaman menjadi menurun. Menurut Gardner (1991), bahwa pemupukan yang berlebihan akan mengakibatkan peningkatan kandungan unsur

\section{KESIMPULAN}

1. Perlakuan terbaik pemberian pupuk NPK Phoska $\mathrm{P}_{2}(1580 \mathrm{~g} /$ tanaman) yaitu rata-rata pertambahan tinggi tanaman umur 90 hari setelah perlakuan tertinggi yaitu $122,33 \mathrm{~cm}$, rata-rata pertambahan diameter batang terbesar yaitu $11,08 \mathrm{~cm}$ dan rata-rata jumlah sisir per tandan terbanyak yaitu 7,22

\section{DAFTAR PUSTAKA}

Anneahira, 2013. Pupuk NPK Phoska. Petrokimia Gersik, Semarang hara tertentu dalan jaringan tanaman, yang menyebabkan pemupukan tidak efisien.

\section{Interaksi Perlakuan Pupuk NPK Phoska dan Pupuk Organik Cair}

Hasil sidik ragam menunjukkan bahwa pengaruh interaksi pemberian pupuk NPK Phoska dan pupuk organik cair tidak berbeda nyata terhadap semua parameter pengamatan yaitu pertambahan tinggi tanaman, pertambahan diameter batang, umur tanaman berbunga dan jumlah sisir per tandan. Tidak adanya perbedaan nyata ini karena perlakuan pemberian pupuk NPK Phoska dan pupuk organik cair tidak terdapat hubungan yang saling mempengaruhi, kedua faktor perlakuan tersebut bertindak bebas satu sama lainnya. Harjadi (2002), menyatakan bahwa perbedaan jenis dan dosis pemupukan yang diberikan akan mempengaruhi kemampuan tanaman dalam meyerap unsur hara dan juga mempengaruhi keadaan fisiologis dan daya tanggap yang berbeda terhadap lingkungan.

Menurut Steel dan Torie (1993), apabila interaksi antara perlakuan yang satu dengan yang lain tidak berbeda nyata, maka dapat disimpulkan bahwa faktor-faktor tersebut bertindak bebas satu sama lain, pengaruh sederhana suatu faktor sama pada semua taraf faktor lainnya. Ditambahkan Jayadi (2002), menyatakan bahwa indeks panen merupakan tolak ukur dari produktifitas tanaman. Indeks panen yang rendah $(<40 \%)$ menunjukkan bahan tanaman tidak produktif. Hasil indeks panen pada penelitian ini bervariasi, namun secara keseluruhan berada pada kisaran di atas 50\% (lampiran 12). Hal ini menunjukkan bahwa walaupun interaksi perlakuan pemberian pupuk NPK Phoska dan pupuk organik cair tidak berpengaruh nyata, namun secara kuantitatif bahan tanaman pisang pada penelitian ini tergolong produktif.

sisir, umur panen tercepat 248 hari setelah tanam.

2. Perlakuan terbaik pemberian pupuk organik cair terhadap rata-rata jumlah sisir per tandan dicapai pada perlakuan $\mathrm{B}_{1}(5000$ $\mathrm{ml}$ ) yaitu 5,33 sisir, umur panen tercepat 248 hari setelah tanam.

3. Interaksi antara pemberian pupuk NPK Phoska dan pupuk organik cair tidak berpengaruh nyata terhadap semua parameter pengamatan.

Balai Penelitian Tanah. 2005. Analisis Kimia Tanah, Tanaman, Air, Dan Pupuk. Badan 
Penelitian Dan Pengembangan Pertanian. Departemen Pertanian, Bogor.

Bapeltan. 2014. Pupuk Organik Cair, Biokultur Plus. Balai Pelatian Pertanian Kalimatan Timur.

Cahyono, B. 1996. Pisang, Budidaya dan Analisis Usaha Tani. Kanisius, Yogyakarta.

Deptan. 2012. Laporan Tahunan Dinas Pertanian Tanaman Pangan Kalimantan Timur 2012. Kalimantan Timur.

Gardner, F. P., Pearce, R. B., dan Mitchell, R. L., 1991. Physiology of Crop Plants. Terjemahan oleh Herawati Susilo. Fisiologi Tanaman Budidaya. UI-Press. Jakarta.

Hanafiah, K.A, 2003. Rancangan Percobaan, Teori dan Aplikasi, Edisi Ketiga, Raja Grafindo Persada, Jakarta.

Hardjowigeno, S. 2007. Ilmu Tanah. Akademika Pressindo, Jakarta.

Harjadi, S.S. 2002. Pengantar Agronomi. Gramedia Pustaka, Jakarta.

Hidayanto, M. , S . Nurjanah ., dan F . Yossita. 2003. Pengaruh Panjang Stek Akar dan Konsentrasi Natrium Nitrofenol Terhadap Pertumbuhan Stek Akar Sukun. Jurnal Pengkajian dan Pengembangan Teknologi Pertanian. Karned.

Indrasaril, A. dan Abdul, 2006. Pengapuran, Pemberian Pupuk Kandang dan Unsur Hara Mikro Terhadap Pertumbuhan Jagung Pada Ultisol yang Dikapur. Jurnal Ilmu Tanah dan Lingkungan.

Jayadi,. 2002. Hubungan Antara Bokhasi Kotoran Ayam dan Pupuk Phospat di Tanah Ultisol dengan Serapan Phospat Terhadap Pertumbuhan dan Hasil Cabe Merah (Capsicum annum, L). Tesis. Program Pascasarjana UNLAM Banjarbaru.

Lingga, P. dan Marsono. 2005. Petunjuk Penggunaan Pupuk. Penebar Swadaya. Jakarta.
Lingga, P. 2007. Petunjuk Penggunaan pupuk. Penebar Swadaya. Jakarta.

Lingga, P dan Marsono, 2010. Petunjuk Penggunaan Pupuk. Penebar Swadaya, Jakarta.

Mulyani, M. 2008. Pupuk dan Cara Pemupukan. Rineka Cipta, Jakarta.

Novizan. 2002. Petunjuk Pemupukan yang Efektif. Agro Media Pustaka, Jakarta.

Pranata, S Ayub, 2004. Pupuk Organik Cair Aplikasi dan Manfaatnya, PT Agromedia Pustaka, Tangerang.

Pitojo dan Setijo. 1997. Penggunaan Urea Tablet. Penebar Swadaya, Jakarta.

Rosmarkam, A. dan N. W. Yuwono., 2002. Ilmu Kesuburan Tanah. Kanisius, Yogyakarta.

Rukmana, R. 1999. Usaha Tani Pisang. Kasinus, Yogyakarta.

Steel, R. G. D. and Torrie, J. H. 1993. Principles and Procedur of Statistic (Terjemahan Bambang Sumantri, Prinsip dan Prosedur Statistika). Gramedia, Jakarta.

Sutanto, R. 2002. Penerapan Pertanian Organik. Kanisius, Yogyakarta.

Sutedjo, M.M. 2010. Pupuk Dan Cara Pemupukan.Rineka Cipta. Jakarta.

Suyanti, Supriyadi dan Ahmad, 2008. Pisang, Budidaya, Pengolahan, dan Prospek pasar. Penerbit Penebar Swadaya, Jakarta.

Wangiyana, W., A. Apriani., N. Farida 2011. Respon Berbagai Varietas Kedelai (Glycine max L) Terhadap Sterilisasi Tanah dan Inokulasi dengan Mikoriza Arbuskular. Agroteksos: (1) : 19 -28.

Wijoseno, B. 2013. Macam-Macam Tanaman Holtikultura Indonesia. Blogspot.co.id. diakses tanggal 10 februari 2015. 